\title{
Food Composition of Wild Boar in North-eastern and Western Poland
}

\author{
Peter GENOV ${ }^{1}$
}

\begin{abstract}
Genov P., 1981: Food composition of wild boar in north-eastern and western Poland. Acta theriol., 26, 10: 185-205 [With 7 Tables \& 3 Figs.]

Examination was made of 192 wild boar stomachs (Sus scrofa Linnaeus, 1758) collected during the period from April 1975 to March 1977 in several areas in north-eastern and western Poland. The entire stomach contents were weighed, then mixed in a bucket, after which a 1-litre sample was taken and fixed in 5\% formalin. Sixty percent of the total stomach contents was analyzed. The percentages of wet plant and animal masses of food were determined, and the composition of the food examined in detail. The wild boar's food includes 131 species (or higher taxons) of plants and animals. It consumes 73 species (or higher taxons) of plants, among which there are 59 plants of forest and meadow associations and 14 species of cultivated plants. Its animal food was found to comprise 57 species (or higher taxons), 45 of which were invertebrates and 12 vertebrates. The wild boar also consumes carrion. Although the wild boar is an omnivorous animal, plants form $91 \%$ of the total mass of its food, and of this $71 \%$ consists of cultivated plants. Animal food ( $9 \%$ of the total food mass) is consumed only in natural habitats and over the course of the whole year.
\end{abstract}

[Inst. of Zoology, University of Warsaw, Krakowskie Przedmieście $26 / 28,00-927 / 1$ Warszawa]

\section{INTRODUCTION}

The wild boar is a typical inhabitant of large forest areas. It prefers wet deciduous forests in which oak and beech occur. The total area of forest land in Poland constitutes about $27 \%$ of the whole country, deciduous tree stands forming only $13 \%$ of wooded land. During the last 100 years the area of deciduous wooded land has constantly decreased over the whole of Western and Central Europe. This situation has greatly contributed to the wild boar's adaptation to new conditions and to its emergence from dense tree stands. Despite the fact that food conditions have deteriorated in natural habitats over the last 30 years, the numbers of wild boar have continued to increase in many European countries. This is due to the lack of large predators, to game protection, to supplementary feeding during periods of scarce food, to high fecundity and the

1 Present address: Inst. of Zoology, Bulgarian Acad. Sci., bul. Ruski 1, 1000-Sofia, Bulgaria.

Acta Theriologica -4 
wide ecological valence of the wild boar. Owing to its considerable capacity for adaptation this species has become a permanent inhabitant of small shelterbelts in fields, and consequently the field habitat is used as a source of food, the agricultural damage done by wild boar therefore constantly increasing. In this connection one of the essential requirements is to determine the composition of the wild boar's diet and its food habits.

Studies of the wild boar's food were based on analysis of stomach and excrement contents, examination of places in which these animals root, and also on observations of feeding wild boar.

Although many authors consider that the wild boar is an omnivorous species, its basic food is formed by plants. Briedermann (1976) states that in the German Democratic Republic the plant food of wild boar forms $90 \%$ of its total food mass. Similar results were obtained by Janda (1958) for Czechoslovakia - 85.8\%, Haber (1966) for Poland - 92.6\% and for the Białowieża Primeval Forest by Sablina (1955) - $86.7 \%$, Lebedeva (1956) $-87.6 \%$, Kozlo $(1975)-95.7 \%$. In the Berezynski reserve during summer, plants form $98.3 \%$ of the wild boar's food (Kozlo, 1972). The percentage of the total food mass formed by cultivated plants is changing. Data of this kind have been given by Briedermann (1968), who stated that in oak and beech seeding years this percentage is from $50-60 \%$ of the total food mass, whereas in years with a poor acorn and beechnut harvest, cultivated plants formed $90 \%$ of its diet. The use made of one or another kind of plant food depends on its abundance in a given area and also on its accessibility. The structure of the landscape is therefore also significant. Where the boundary line between field and woodland is long, the wild boar makes greater use of cultivated fields. The structure of distribution of different crops and their area is also of considerable importance in the way use is made of plant food from cultivated fields. The closer to the forest and the greater the area of the given crop, the greater the extent to which the wild boar visits the fields, since such fields both provide attractive food and the possibility of undisturbed feeding. Among the crops cultivated in Europe the most attractive food for wild boar consists of potatoes and oats, and also maize. (Janda, 1958; Sumiński, 1963; Haber, 1966; 1968, 1969; Briedermann, 1968, 1976; Dormidontov, 1967; Varnakov \& Moseva, 1975; Pasławski, 1976; Lozan et al:, 1978). These plants form the wild boar's basic food in spring, summer and autumn.

The composition of the wild boar's food has been examined to answer the question as to how intensively these animals make use of woodland and field habitats, and in consequence to determine the wild boars role in these biocenoses and its place in the food chain. 


\section{STUDY AREA, MATERIAL AND METHODS}

Examination was made of 192 wild boar stomachs collected from April 1975 to March 1977. Among these 11 were empty in spring $(5.7 \%), 4$ in autumn $(4.5 \%)$ and 7 in winter $(10.2 \%)$. The stomachs were obtained in two regions of Poland: in the north-eastern region the material originated from the Kuzie and Serafin forest districts - 13, Smolniki -17 , from the Pelplin Animal Breeding Centre

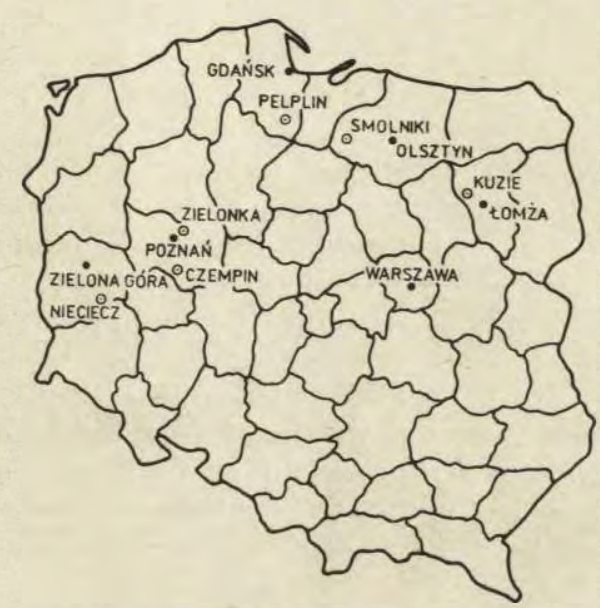

Fig. 1. Places in which samples of the contents of wild boar's stomachs were abtained.

Table 1 .

Number, age, sex and shooting time of wild boar's collected for the study.

\begin{tabular}{llccr}
\hline \multirow{2}{*}{ Age group } & \multicolumn{2}{c}{ Shooting time (hrs) } & \\
\cline { 3 - 4 } & & $00.00-12.00$ & $13.00-24.00$ & Total \\
\hline \multirow{2}{*}{ Piglets: } & Males & 12 & 33 & 45 \\
& Females & 15 & 26 & 41 \\
One year old: & Males & 13 & 17 & 30 \\
& Females & 5 & 24 & 29 \\
Adults: & Males & 19 & 12 & 31 \\
& Females & 4 & 12 & 16 \\
Total & & 68 & 124 & 192 \\
\hline
\end{tabular}

of the Polish Hunting Association (ABC PHA) - 119, which formed a total of 149 stomachs. Samples obtained from this region in spring number 9 , in summer -14 , in autumn -68 , in winter 58. In the western regions of Poland the material was obtained from the Nieciecz ABC PHA - 12, from the Czempin PHA Research Station - 23, and the Zielonka Experimental Centre of Poznan Agricultural Academy -8 , totalling 43 (Fig. 1). In this series there were 5 stomachs in 
spring, 7 in summer, 21 in autumn and 10 in winter. The material was obtained from animals shot during the hunting season, and from individuals specially shot for these studies (spring period). Wild boars were shot at different times over the whole 24-hour period. The amount of study material divided into age classes and sex is shown in Table 1.

Before analysis the whole stomach contents were weighed, then the contents were mixed in a bucket and a 1-litre sample taken, which was next immersed in $5 \%$ formalin solution. Analysis was made of $127.8 \mathrm{~kg}$ of fixed food mass, which formed $60 \%$ of the total food. The proportions of plant and animal food were determined. The composition of the food was examined in the greatest possible detail, using the method given by Dzięciolowski (1967) and Rzebik-Kowalska (1972).

Use was also made of 406 samples of forest litter and soil, and also 20 samples of excrement collected during the winter periods to supplement the list of foods. Direct observations of three tame wild boar while feeding were also used for this purpose, continuing the observations over a period of 30 days in spring, summer and winter. These data form the subject of a separate publication (Genov, in print).

Frequency of occurrence of food components in percentages of the number of stomachs containing food, the weight of food components (in grammes) and percentage of components in the weight of food were compared between the regions from which the material had been obtained.

\section{RESULTS}

\subsection{Composition of the Wild Boar's Food}

The following were identified in the material obtained: 41 species or higher taxons of woodland and meadow plants, 18 species of bushes and shrubs, 14 species of cultivated plants, 45 species or higher taxons of invertebrates, 12 species of vertebrates, and carrion. A total of 131 kinds of food consumed by the wild boar at different times of the year were found (Table 2).

\subsection{Weight of Food in the Stomach}

Using stomach contents as a basis, an attempt was made at determining the wild boar's activity over a 24 -hour period. It was found that the weight of stomach contents obtained from midnight to 12.00 is greater in all age classes and sex than in stomachs obtained between the hours of 12.00 to 24.00 (Table 3). Some of the wild boar hunted and shot had empty stomachs (in autumn and winter 6 empty stomachs in very young animals, 3 in animals over one year old and 2 in adult males). An exception was a 4-year old male shot towards the end of November (sexual heat period) at 10.30 . 
Table 2

Composition of wild boar's diet.

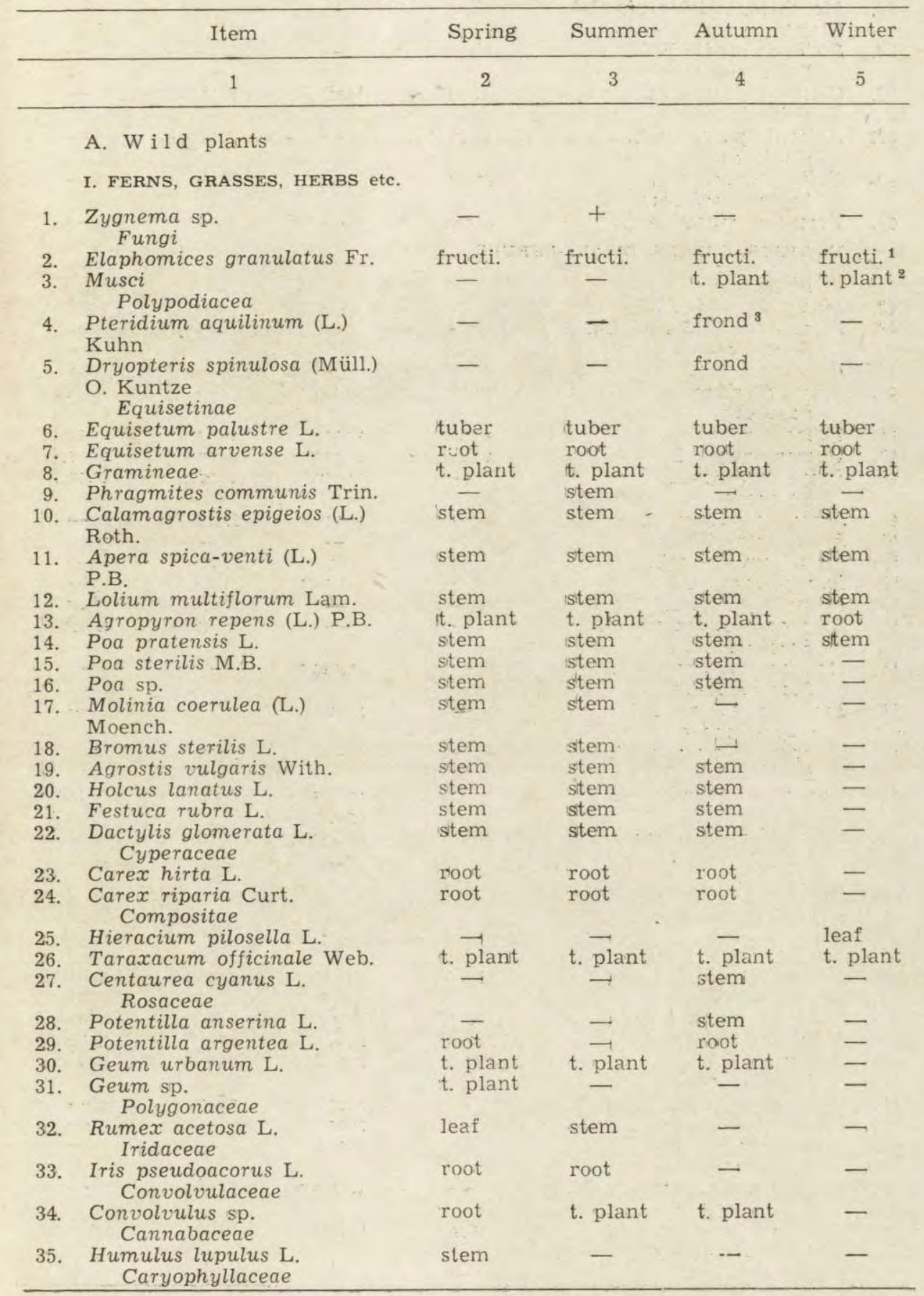




\begin{tabular}{|c|c|c|c|c|c|}
\hline & 1 & 2 & 3 & 4 & 5 \\
\hline 36. & $\begin{array}{l}\text { Moechringia trinervia (L.) } \\
\text { Clairv. }\end{array}$ & stem & - & 一 & - \\
\hline 37. & $\begin{array}{l}\text { Stellaria media Will. } \\
\text { Ranunculaceae }\end{array}$ & stem & - & 一 & 一 \\
\hline 38. & $\begin{array}{l}\text { Caltha palustris } \mathrm{L} . \\
\text { Primulaceae }\end{array}$ & r. stóck & leaf & r. stock ${ }^{4}$ & - \\
\hline 39. & $\begin{array}{l}\text { Hottonia palustris L. } \\
\text { Rubiaceae }\end{array}$ & r. stock & - & r. stock & - \\
\hline 40. & $\begin{array}{l}\text { Galium aparine L. } \\
\text { Scrophulariaceae }\end{array}$ & stem & - & 一 & - \\
\hline 41. & $\begin{array}{l}\text { Veronica triphyllos L. } \\
\text { II. TREES, SHRUBS, DWARF-SHF }\end{array}$ & stem & - & - & - \\
\hline & Pinaceae & & & & \\
\hline 42. & Pinus silvestris L. & 一 & - & root & root \\
\hline 43. & $\begin{array}{l}\text { Picea excelsa (Lam.) Lk. } \\
\text { Betulaceae }\end{array}$ & $\rightarrow$ & 一 & root & root \\
\hline 44. & Betula sp. & root & $\overline{1}$ & folliage & root \\
\hline 45. & $\begin{array}{l}\text { Alnus glutinosa (L.) Gaertn. } \\
\text { Fagaceae }\end{array}$ & noat & foliage & - & foliage \\
\hline 46. & Quercus robur $\mathrm{L}$. & acorn & acorn & acorn & acorn \\
\hline 47. & Quercus rubra L. & acorn & acorn & acorn & acorn \\
\hline 48. & $\begin{array}{l}\text { Fagus silvatica L. } \\
\text { Rosaceae }\end{array}$ & - & acorn & acorn & acorn \\
\hline 49. & Sorbus aucuparia L. & - & root & fruit & - \\
\hline 50. & Rosa canina $\mathrm{L}$. & 一 & - & $\rightarrow$ & fruit \\
\hline 51. & Pirus communis L. & - & fruit & fruit & - \\
\hline 52. & Rubus idaeus L. & - & foliage & - & - \\
\hline 53. & Prunus spinosa L. & - & - & fruit & fruit \\
\hline 54. & $\begin{array}{l}\text { Crataegus oxyacantha } \mathrm{L} . \\
\text { Berberidaceae }\end{array}$ & - & - & fruit & fruit \\
\hline 55. & $\begin{array}{l}\text { Machonia aquifolium L. } \\
\text { Saxifragaceae }\end{array}$ & 一 & foliage & - & - \\
\hline 56. & $\begin{array}{l}\text { Ribes grossularia L. } \\
\text { Cupressaceae }\end{array}$ & - & fruit & 一 & - \\
\hline 57. & $\begin{array}{l}\text { Juniperus communis L. } \\
\text { Ericaceae }\end{array}$ & 一 & - & root & roct \\
\hline 58. & Vaccinium myrtillus L. & root & $\begin{array}{l}\text { foliage } \\
\text { fruit }\end{array}$ & root & $\begin{array}{l}\text { r. stock } \\
\text { root. }\end{array}$ \\
\hline 59. & Vaccinium vitis-idaea L. & root & $\begin{array}{l}\text { foliage } \\
\text { fruit }\end{array}$ & root & $\begin{array}{l}\text { r. stock } \\
\text { root }\end{array}$ \\
\hline & $\begin{array}{l}\text { B. Cultiva te d plants } \\
\text { I. GRASSES, HERBS }\end{array}$ & & & & \\
\hline 60. & $\begin{array}{c}\text { Gramineae } \\
\text { Cecale cereale L. }\end{array}$ & stem & grain & grain & grain \\
\hline 61. & Avena sativa $\mathrm{L}$. & si & grain & grain & grain \\
\hline 62 & Triticum vulgare Vill. & stem & grain & grain & grain \\
\hline 63. & Hordeum vulgare L. & stem & grain & grain & grain \\
\hline 64. & $\begin{array}{l}\text { Zea mays L. } \\
\text { Papilionaceae }\end{array}$ & grain & grain & grain & grain \\
\hline 65. & Lupinus luteus L. & - & stem & stem & - \\
\hline 66. & Phaseolus vulgaris L. & - & stem & - & - \\
\hline 67. & $\begin{array}{l}\text { Pisum sativum L. } \\
\text { Polygonaceae }\end{array}$ & - & stem & & - \\
\hline 68. & $\begin{array}{l}\text { Fagopyrum sagittatum Gilib. } \\
\text { Solanaceae }\end{array}$ & - & & grain & - \\
\hline 69. & $\begin{array}{l}\text { Solanum tuberosum L. } \\
\text { Chenopodiaceae }\end{array}$ & tuber & tuber & tuber & Ituber \\
\hline 70. & Beta vulgaris L. & 一 & + & + & + \\
\hline
\end{tabular}




\begin{tabular}{|c|c|c|c|c|c|}
\hline & 1 & 2 & 3 & 4 & 5 \\
\hline 71. & $\begin{array}{l}\text { Compositae } \\
\text { Lactuca sativa L. } \\
\text { II. TREES }\end{array}$ & - & stem & - & - \\
\hline $\begin{array}{l}72 . \\
73 .\end{array}$ & $\begin{array}{l}\text { Rosaceae } \\
\text { Pirus communis L. } \\
\text { Malus domestica Borb. }\end{array}$ & 二 & $\begin{array}{l}\text { fruit } \\
\text { fruit }\end{array}$ & fruit & fruit \\
\hline & $\begin{array}{l}\text { Malus domestica Borb. } \\
\text { C. A n imal food } \\
\text { I. INVERTEBRATES }\end{array}$ & & & & \\
\hline $\begin{array}{l}74 . \\
75 .\end{array}$ & $\begin{array}{l}\text { Lumbricidae } \\
\text { Lumbricus sp. } \\
\text { Dendrobaena sp. } \\
\text { Helicidae }\end{array}$ & $\dot{+}+$ & $\stackrel{+}{+}$ & + & $\stackrel{+}{+}$ \\
\hline $\begin{array}{l}76 . \\
77 .\end{array}$ & $\begin{array}{l}\text { Helix pomatia } \mathrm{L} . \\
\text { Avionidae }\end{array}$ & $\stackrel{+}{+}$ & $\stackrel{+}{+}$ & $\begin{array}{l}+ \\
+\end{array}$ & + \\
\hline 78. & $\begin{array}{l}\text { Araneida indet: } \\
\text { Forficulidae }\end{array}$ & 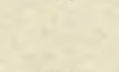 & & & \\
\hline 79. & $\begin{array}{l}\text { Forficula sp. } \\
\text { Lepidoptera }\end{array}$ & - & - & - & imago \\
\hline 80. & Lepidoptera indet. & 一 & larva & coccon & coccon \\
\hline $\begin{array}{l}81 . \\
82 .\end{array}$ & & 二 & $\begin{array}{l}\text { larva } \\
\text { larva }\end{array}$ & - & 二 \\
\hline 83. & $\begin{array}{l}\text { Sphingidae: Sphinx } \\
\text { pinastri L. }\end{array}$ & pupa & $\longrightarrow$ & pupa & pupa \\
\hline 84. & $\begin{array}{l}\text { Geometrinae: Bupalus } \\
\text { piniarius L. } \\
\text { Tipulidae }\end{array}$ & pupa & - & pupa & pupa \\
\hline 85. & Tipula sp. & larva & larva & larva & larva \\
\hline 86. & $\begin{array}{l}\text { Tipula (subg. Lunatipula) } \\
\text { livida v.d. Wulp }\end{array}$ & + & + & + & + \\
\hline 87. & $\begin{array}{l}\text { Tipula (subg. Pterelachisus) } \\
\text { hartulana) L. }\end{array}$ & + & - & $\rightarrow$ & - \\
\hline 88. & $\begin{array}{l}\text { Tipula (subg. Tipula cziezki) } \\
\text { de Jong }\end{array}$ & + & - & + & + \\
\hline 89. & $\begin{array}{l}\text { Tipula (subg. Vestiplex) } \\
\text { nubeculosa Mg. }\end{array}$ & + & 一 & + & - \\
\hline 90. & $\begin{array}{l}\text { Tipula (subg. Acutipula) } \\
\text { vittata } \mathrm{Mg} \text {. }\end{array}$ & $\rightarrow$ & - & + & - \\
\hline 91. & $\begin{array}{l}\text { Tipula (subg. Vestiplex) } \\
\text { scripta Mg. }\end{array}$ & $一$ & 一 & + & - \\
\hline $\begin{array}{l}92 . \\
93 .\end{array}$ & $\begin{array}{l}\text { Tipula (subg. Pterelachisus) sp. } \\
\text { Lonchalidae } \\
\text { Bibionidae }\end{array}$ & $\begin{array}{c}+ \\
\text { pupa }\end{array}$ & 二 & \pm & - \\
\hline 94. & Bibio sp. & larva & larva & larva & larva \\
\hline 95. & Bibio johannis (L.) & 一 & - & + & - \\
\hline 96. & Bibio marci (L.) & - & - & + & + \\
\hline 97. & Bibio pomonae (Fabr.) & 一 & 二 & + & \pm \\
\hline 98. & $\begin{array}{l}\text { Muscidae-Polietes lardaria } \mathrm{F} \text {. } \\
\text { Elateridae }\end{array}$ & - & - & larva & - \\
\hline 99. & Elater sp. & imago & - & larva & imago \\
\hline 100. & Athous niger L. & imago & -- & larva & imago \\
\hline 101. & Selatosomus aeneus L. & - & - & - & imago \\
\hline 102. & $\begin{array}{l}\text { Corymbites castaneus L. } \\
\text { Carabidae }\end{array}$ & - & -- & - & imago \\
\hline 103. & Carabus sp. & - & 一 & larva & imago \\
\hline 104. & Harpalus affinis (Schrank) & - & - & imago & - \\
\hline $\begin{array}{l}105 . \\
106 .\end{array}$ & $\begin{array}{l}\text { Agonuns vidnum (Panz.) } \\
\text { Carabus nemoralis }\end{array}$ & $\rightarrow$ & 二 & $\begin{array}{l}\text { imago } \\
\text { imago }\end{array}$ & $\overline{-}$ \\
\hline & (O. F. Müll.) & & & & \\
\hline
\end{tabular}




\begin{tabular}{|c|c|c|c|c|c|}
\hline & 1 & 2 & 3 & 4 & 5 \\
\hline 107. & $\begin{array}{l}\text { Pterostichus } \\
\text { oblongopunctatus F. }\end{array}$ & - & - & larva . & - \\
\hline 108. & Carabus arvensis Hbst. & - & 一 & larva & 一 \\
\hline 109. & $\begin{array}{l}\text { Calosoma sycophanta L. } \\
\text { Ditiscidae }\end{array}$ & 一 & 一 & larva & - \\
\hline 110. & $\begin{array}{l}\text { Hydaticus transversalis } \\
\text { Pont. }\end{array}$ & $\longrightarrow$ & 一 & imago & - \\
\hline 111. & Ilybius obscurus $\mathrm{F}$. & - & 一 & imago & - \\
\hline 112. & $\begin{array}{l}\text { Cantharidae } \\
\text { Staphylinidae }\end{array}$ & - & - & larva & - \\
\hline $\begin{array}{l}113 . \\
114 .\end{array}$ & $\begin{array}{l}\text { Staphylinus sp. } \\
\text { Melolontha sp. } \\
\text { Cerambycidae }\end{array}$ & 二 & - & imago & larva \\
\hline 115. & Tetropium sp. & - & 一 & $\longrightarrow$ & imago \\
\hline 116. & $\begin{array}{l}\text { Spondylis buprestoides L. } \\
\text { Scarabaeidae }\end{array}$ & larva & - & - & - \\
\hline 117. & $\begin{array}{l}\text { Aphodius subterraneus } \\
\text { a. fuscipennis (Müll) } \\
\text { Hymenoptera }\end{array}$ & - & imago & 一 & - \\
\hline 118. & $\begin{array}{l}\text { Diprion pini L. } \\
\text { II. VERTEBRATES }\end{array}$ & coccon & - & coccon & coccon \\
\hline $\begin{array}{l}119 . \\
120 .\end{array}$ & $\begin{array}{l}\text { Pisces: Cyprinus carpio L. } \\
\text { Amphibia }\end{array}$ & - & $\stackrel{+}{+}$ & 二 & 二 \\
\hline 121. & $\begin{array}{l}\text { Bufo viridis Laurenti } \\
\text { Aves }\end{array}$ & - & f. grown & 二 & $\overline{-}$ \\
\hline $\begin{array}{l}122 . \\
123 .\end{array}$ & $\begin{array}{l}\text { Gallus domesticus L. }{ }^{*} \\
\text { Phasianus colchicus L. }\end{array}$ & chick & chick & $\begin{array}{l}\text { chick } \\
\text { nestling }\end{array}$ & f. fled $^{5}$ \\
\hline 124. & $\begin{array}{l}\text { Passer indet. } \\
\text { Mammalia }\end{array}$ & $\overline{-}$ & $\exists$ & nestling & - \\
\hline $\begin{array}{l}125 . \\
126 .\end{array}$ & Apodemus silvaticus (L.) & - & f. grown 6 & - & $\overrightarrow{a r o w}$ \\
\hline $\begin{array}{l}126 . \\
127 .\end{array}$ & $\begin{array}{l}\text { Apodemus agrarius }(\mathrm{P} \\
\text { Apodemus flavicollis }\end{array}$ & f. $\overline{\text { grown }}$ & $\begin{array}{l}\text { f. grown } \\
\text { f. grown }\end{array}$ & f. grown & $\begin{array}{l}\text { f. grown } \\
\text { f. grown }\end{array}$ \\
\hline & (Melchior) & & & 1. grown & f. grown \\
\hline 128. & $\begin{array}{l}\text { Talpa europaea L. } \\
\text { Capreolus capreolus }\end{array}$ & - & 一 & f. grown & - \\
\hline 129 & $\begin{array}{l}\text { Capreolus capreolus (L.) - } \\
\text { carion }\end{array}$ & - & 一 & - & f. grown \\
\hline 130 & $\begin{array}{l}\text { Milk } \\
\text { Carion _ indet }\end{array}$ & $一$ & + & 一 & - \\
\hline 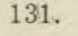 & Carion - indet. & + & + & + & + \\
\hline
\end{tabular}

* food from supplementary feeding; + , food residues present, - , food items absent.

${ }^{1}$ fructi. - fructification (sporocarp of fungi); ${ }^{2}$ t. plant - total plant; ${ }^{3}$ frond (of ferns); ${ }^{4}$ r. stock - root stock; ${ }^{5}$. fled - full fledged; ${ }^{6} \mathrm{f}$. grown - full grown.

Differences in the weight of stomach contents were tested by means of the Student $t$ test at a level of significance of $p=0.05$. It was shown that the difference between the average weights of stomach contents in wild boar obtained up to midday and after midday are significant in the case of the young animals of both sexes and adult males. In the case of animals over one year old and adult females these differences proved to be statistically insignificant.

The weight of stomach contents for adult males and females differs 
to a statistically significant degree, while analogical differences in the piglets and those boars over one year old were not significant (Table 3).

Table 3

Weight of stomach contents (in grammes of wet fixed mass) of wild boar's, according to age, sex and shooting time. Data for all seasons.

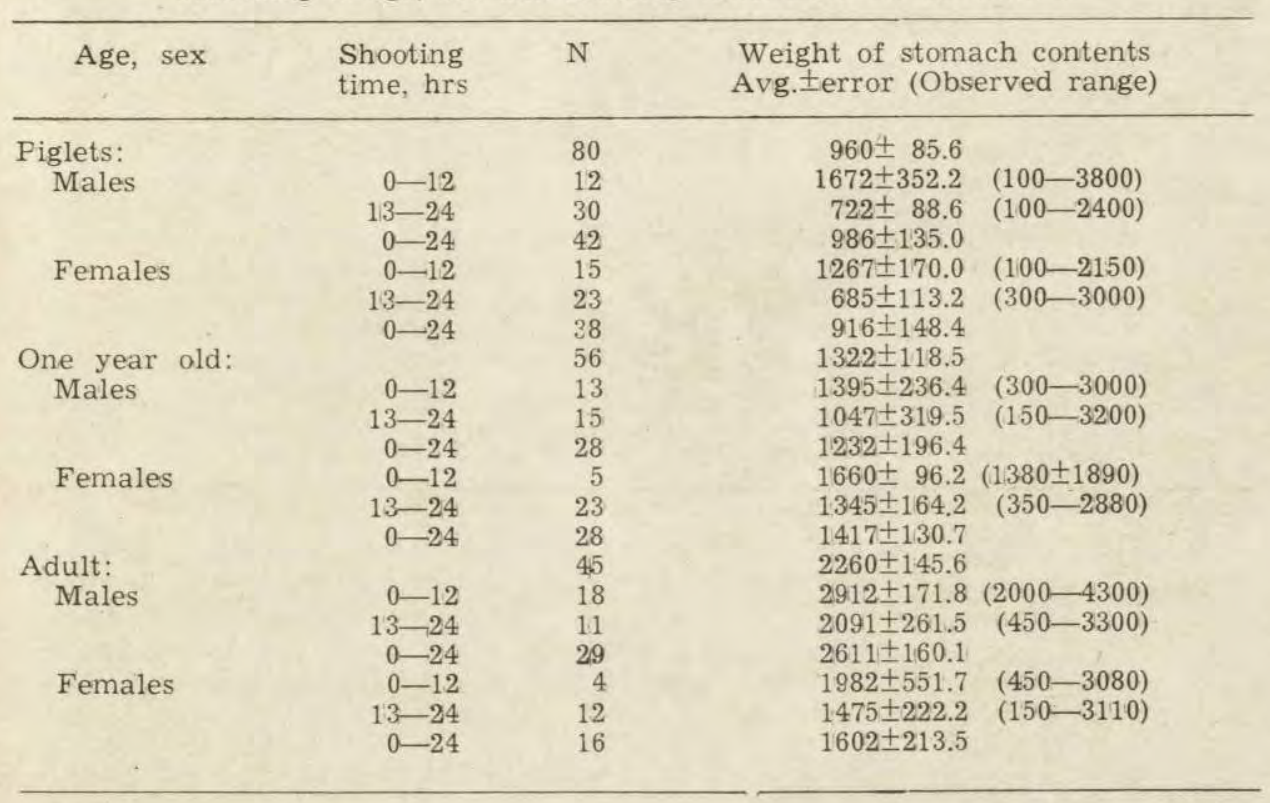

3.3. Frequency of Occurrence of Different Types of Food and their Percentages of Stomach Contents

In 181 stomachs out of 192 food residues were found and analyzed. Plants were encountered in all the stomachs analyzed, with the exception of those from winter, of which 2 stomachs $(1.1 \%)$ were filled with chicken offal originating from supplementary feeding, and did not contain plants.

Most often cultivated plants forming the wild boar's basic food were found. They occurred in $89 \%$ of the stomachs containing food (Table 4), and constitute on an average $71.0 \%$ in the weight of stomach contents. Their mean weight was $918 \mathrm{~g}$. In summer cultivated plants occur in all stomachs. The mean percentage of stomach contents is also greatest in summer, whereas maximum mean weight occurs in autumn. During the summer period wild boar feed more often on the stems of cultivated plants, and in autumn on tubers and grain. Stems have a greater volume but lower weight than tubers and grain, and consequently their greater volume occurs during one period, and their greatest weight in another. 
Woodland and meadow herbs and grasses take second place after cultivated plants in the wild boar's food (Table 4). On an average the former were encountered annually in $64 \%$ of stomachs containing consumed food, and the mean annual percentage and weight of this type of food in relation to stomach contents was $20 \%$ and $256 \mathrm{~g}$. In spring the percentage and weight of these plants is greatest and is of first importance during this period. Woodland and meadow plants form food very attractive to the wild boar.

\section{Table 4}

Role of plant and animal food in the wild boar's diet. A - Frequency of occurrence in per cent of total number of stomachs, B - Average weight \pm S.E. in grammes,

C - Percentage participation in total mass of stomach contents \pm S.E.

\begin{tabular}{|c|c|c|c|c|c|}
\hline Season & & $\begin{array}{l}\text { Plant food } \\
\text { (Total) }\end{array}$ & $\begin{array}{l}\text { Cultivated } \\
\text { plants }\end{array}$ & $\begin{array}{l}\text { Wood \& } \\
\text { meadow } \\
\text { plants }\end{array}$ & $\underset{\text { food }}{\text { Animal }}$ \\
\hline Spring $(n=14)$ & $\begin{array}{l}\text { A } \\
\text { B } \\
\text { C }\end{array}$ & $\begin{array}{c}100.0 \\
1346 \pm 328 \\
78.3 \pm 7.8\end{array}$ & $\begin{array}{c}71.4 \\
848 \pm 254 \\
52.3 \pm 11.3\end{array}$ & $\begin{array}{c}78.6 \\
503 \pm 222 \\
26.0 \pm 7.8\end{array}$ & $\begin{array}{c}78.6^{1} \\
256 \pm 112 \\
21.7 \pm 7.8\end{array}$ \\
\hline Summer $(n=21)$ & $\begin{array}{l}\mathrm{A} \\
\mathrm{B} \\
\mathrm{C}\end{array}$ & $\begin{array}{c}100.0 \\
1098 \pm 248 \\
95.9 \pm 2.4\end{array}$ & $\begin{array}{c}100.0 \\
962 \pm 231 \\
82.4 \pm 4.4\end{array}$ & $\begin{array}{c}66.7 \\
135 \pm 50 \\
13.4 \pm 3.7\end{array}$ & $\begin{array}{c}38.0 \\
28 \pm 15 \\
4.1 \pm 2.4\end{array}$ \\
\hline Autumn $(\mathrm{n}=85)$ & $\begin{array}{l}\mathrm{A} \\
\mathrm{B} \\
\mathrm{C}\end{array}$ & $\begin{array}{c}100.0 \\
1263 \pm 90 \\
97.1 \pm 1.3\end{array}$ & $\begin{array}{c}91.8 \\
1061 \pm 99 \\
77.7 \pm 3.7\end{array}$ & $\begin{array}{c}63.5 \\
203 \pm 43 \\
19.4 \pm 3.6\end{array}$ & $\begin{array}{c}31.0 \\
38 \pm 17 \\
2.9 \pm 1.3\end{array}$ \\
\hline Winter $(n=61)$ & $\begin{array}{l}\mathrm{A} \\
\mathrm{B} \\
\mathrm{C}\end{array}$ & $\begin{array}{c}96.7 \\
986 \pm 109 \\
91.5 \pm 2.3\end{array}$ & $\begin{array}{c}85.3 \\
802 \pm 112 \\
71.4 \pm 4.9\end{array}$ & $\begin{array}{c}47.5 \\
183 \pm 61 \\
21.1 \pm 4.9\end{array}$ & $\begin{array}{r}41.0^{2} \\
1117 \pm 67 \\
8.5 \pm 2.6\end{array}$ \\
\hline Whole year $(n=181)$ & $\begin{array}{l}\text { A } \\
\text { B } \\
\text { C }\end{array}$ & $\begin{array}{c}99.0 \\
1171 \\
191.0\end{array}$ & $\begin{array}{c}89.0 \\
918 \\
71.0\end{array}$ & $\begin{array}{c}64.0 \\
256 \\
20.0\end{array}$ & $\begin{array}{c}47.0 \\
108 \\
9.0\end{array}$ \\
\hline
\end{tabular}

'Supplementary fed by chicken offal, ${ }^{2}$ Two stomachs containing chicken offal.

In general plant food forms the wild boar's basic food over the whole year. It occurs in $99 \%$ of the stomachs and forms $91 \%$ of the average stomach contents (Table 4).

Animal food was on an average contained in $47 \%$ of the stomachs containing food. The mean percentage of animal food in stomach contents was $9 \%$ and its weight $11 \mathrm{~g}$. This type of food is thus not of real importance in the wild boar's diet (Table 4).

\subsection{The Role of Upper and Underground Parts of Plants in the Wild Boar's Food}

Frequency of occurrence of the upper parts of plants is greatest in spring $(92.2 \%$ of the total number of stomachs containing food), and lowest in winter $(55.7 \%$ ). Food consisting of the underground parts of 
plants occurs most often in winter $(78.7 \%)$ and least often in spring $(50 \%)$ - (Table 5).

Opportunities for the wild boar to consume plant food found above or below ground differ depending on climatic conditions and the season. The inaximum percentage of the upper parts of plants occurs in summer

Tabela 5

Role of upper and underground parts of plants in the plant food of the wild boar.

A - Frequency of occurrence in per cent of total number of stomachs,

B - Average weight \pm S.E. in grammes,

C - Percentage participation in total mass of stomach contents \pm S.E.

\begin{tabular}{|c|c|c|c|}
\hline Season & & $\begin{array}{l}\text { Parts } \\
\text { upper }\end{array}$ & $\begin{array}{l}\text { of plants: } \\
\text { underground }\end{array}$ \\
\hline Spring $(n=14)$ & $\begin{array}{l}\mathrm{A} \\
\mathrm{B} \\
\mathrm{C}\end{array}$ & $\begin{array}{c}92.2 \\
973 \pm 285 \\
55.4 \pm 8.2\end{array}$ & $\begin{array}{c}50.0 \\
352 \pm 154 \\
17.6 \pm 7.7\end{array}$ \\
\hline Summer $(n=21)$ & $\begin{array}{l}\mathrm{A} \\
\mathrm{B} \\
\mathrm{C}\end{array}$ & $\begin{array}{c}95.2 \\
735 \pm 205 \\
69.0 \pm 8.0\end{array}$ & $\begin{array}{c}62.0 \\
363 \pm 158 \\
26.8 \pm 7.3\end{array}$ \\
\hline Autumn $(n=85)$ & $\begin{array}{l}\mathrm{A} \\
\mathrm{B} \\
\mathrm{C}\end{array}$ & $\begin{array}{c}77.7 \\
717 \pm 92 \\
58.6 \pm 4.8\end{array}$ & $\begin{array}{c}60.0 \\
547 \pm 88 \\
38.6 \pm 4.7\end{array}$ \\
\hline Winter $(n=61)$ & $\begin{array}{l}\mathrm{A} \\
\mathrm{B} \\
\mathrm{C}\end{array}$ & $\begin{array}{c}55.7 \\
268 \pm 63 \\
28.6 \pm 4.5\end{array}$ & $\begin{array}{c}78.7 \\
716 \pm 108 \\
62.9 \pm 5.5\end{array}$ \\
\hline Whole year $(n=181)$ & $\begin{array}{l}\text { A } \\
\text { B } \\
\text { C }\end{array}$ & $\begin{array}{r}73.5 \\
673.5 \\
53.0\end{array}$ & $\begin{array}{r}65.8 \\
498.5 \\
36.5\end{array}$ \\
\hline
\end{tabular}

$(69 \%)$, and lowest in winter $\left(28.6^{0} \%\right)$. The reverse applies to food found underground: in winter $-62.9 \%$, spring $17.6 \%$. In general $53.0 \%$ of the upper parts of plants and $36.5 \%$ of underground parts are consumed by the wild boar.

\subsection{The Role of Different Food Components in the Wild Boar's Diet over the Yearly Cycle}

- Potatoes form the highest percentages of food found in the stomachs examined. The range of percentages is considerable and varies from 0 to $100 \%$ (Table 6). They form one of the basic components of the wild boar's food. In addition to potatoes, sugar beet is supplied to wild boar as supplementary food in autumn and winter, but it does not form a basic component of their diet.

Although maize is very attractive to wild boar, it only occured in small amounts in stomach samples, probably due to the fact that maize is not a widely cultivated crop in Poland. Although maize is used for 
Table 6

Role of different components A - Frequency of occurrence in per cent of total number of stomachs, B - Avestomach contents \pm S.E.

\begin{tabular}{|c|c|c|c|c|c|c|}
\hline Item & A & $\underset{B}{\text { Spring }}$ & C & A & $\underset{\mathrm{B}}{\text { Summer }}$ & C \\
\hline Potatoes & 50 & $124 \pm 54$ & $17 \pm 7$ & 42.9 & $546 \pm 234$ & $31 \pm 8$ \\
\hline Maize & 21.4 & $71 \pm 41$ & $12.6 \pm 8$ & 33.3 & $166 \pm 73$ & $20.3 \pm 7.7$ \\
\hline Sugar beets & - & - & - & 4.8 & $1.2 \pm 1.2$ & $0.23 \pm 0.23$ \\
\hline Oat & 28.6 & $106 \pm 60$ & $15 \pm 8.3$ & 42.9 & $151 \pm 57$ & $19.3 \pm 7.3$ \\
\hline Rye & - & - & - & 33.3 & $7.3 \pm 4.5$ & $8.4 \pm 3.9$ \\
\hline Wheat & - & - & - & 9.5 & $43 \pm 3.6$ & $0.95 \pm 0.66$ \\
\hline Leguminous plants & - & - & - & 19 & $22 \pm 14$ & $2.9 \pm 1.7$ \\
\hline Acorns & - & - & - & 14.3 & $12 \pm 5$ & $2.3 \pm 1.7$ \\
\hline Annual plants & 78.6 & $233 \pm 57$ & $25.8 \pm 6.4$ & 52.4 & $117 \pm 51$ & $9.5 \pm 3.3$ \\
\hline Roots & 7.1 & $0.36 \pm 0.36$ & $0.05 \pm 0.05$ & 13 & $6.6 \pm 5.7$ & $1.3 \pm 1.1$ \\
\hline Fungi & $-\overline{0} 0$ & - & - & - & - & $\overline{+0}$ \\
\hline $\begin{array}{l}\text { Invertebrates } \\
\text { Vertebrates }\end{array}$ & 28.6 & $0.6 \pm 0.3$ & $0.09 \pm 0$ & 14.3 & $15 \pm 14$ & $2.5 \pm 2.4$ \\
\hline Vertebrates & 57.1 & $293 \pm 113$ & $27 \pm 8.5$ & 33.3 & $13 \pm 6.5$ & $1.7 \pm 0.79$ \\
\hline
\end{tabular}

supplementary winter feeding for wild boar, only relatively small amounts are provided.

Like maize, oats are among the most attractive foods to wild boar. When it is remembered that oats are relatively more seldom cultivated in the lowlands of Poland than rye, potatoes or maize, it could be concluded that it is one of the most preferred and sought kinds of food. Oats are also used for supplementary feeding of these animals in autumn and winter, and in addition they feed on the bundles of oats laid out in winter for roe deer.

Rye and wheat form only a very small percentage of the wild boar's food, although both these grains are used for supplementary feeding for these animals in winter. In autumn, winter and spring wild boar consume the green mass of rye and wheat, and in summer also eat the grain.

Only negligible amounts of leguminous plants are consumed by wild boar, mostly pea and lupin, chiefly in summer and autumn in western Poland. Only a small percentage of acorns occurred in the stomachs, as a result of the samples having been taken in greater amounts from the north-eastern region of Poland, where there are few oaks, than from western Poland where there are more of these trees, and consequently the average for the whole material was reduced (Table 6).

Annual plants of woodiand and meadow associations formed the basic food in spring, and are encountered in the greatest number of stomachs at that time. They also form the greatest percentage of stomach contents during this period. Decrease occurs in the winter on account of the small number of species remaining green in winter. 
of the wild boar's diet.

rage weight \pm S.E. in grammes, C - Percentage participation in total mass of

\begin{tabular}{|c|c|c|c|c|c|c|c|c|}
\hline A & $\underset{\text { B }}{\text { Autumn }}$ & C & A & $\underset{\mathrm{B}}{\text { Winter }}$ & C & A & $\underset{B}{\text { Whole year }}$ & $\mathrm{C}$ \\
\hline 54.1 & $367 \pm 74$ & $26 \pm 4$ & 52.5 & $278 \pm 67$ & $27 \pm 5$ & 52 & 328.8 & 30.5 \\
\hline 41.2 & $373 \pm 74$ & $26.6 \pm 4$ & 5 & $9.9 \pm 7.2$ & $0.94 \pm 0.58$ & 27 & 155 & 14.3 \\
\hline 18.8 & $225 \pm 72$ & $13 \pm 3$ & 39.3 & $339 \pm 89$ & $21.6 \pm 4.6$ & 23 & 141.3 & 13.0 \\
\hline 17.7 & $55 \pm 24$ & $8 \pm 2$ & 32.8 & $98.5 \pm 35$ & $12.2 \pm 3.1$ & 27 & 102.6 & 9.4 \\
\hline 14.1 & $21 \pm 10$ & $2.9 \pm 0.99$ & 3.3 & $4.2 \pm 3.9$ & $1.7 \pm 1.6$ & 12 & 8.1 & 0.9 \\
\hline- & - & - & 10 & $76 \pm 39$ & $9.6 \pm 3.2$ & 1 & 29.7 & 2.6 \\
\hline 2.4 & $6.4 \pm 4.5$ & $0.38 \pm 0.28$ & - & - & - & 3 & 7.1 & 0.7 \\
\hline 36.8 & $155 \pm 38$ & $15.2 \pm 3.4$ & 8.2 & $87 \pm 42$ & $6.7 \pm 2.7$ & 22 & 63.5 & 5.8 \\
\hline 22.4 & $26 \pm 10$ & $2.6 \pm 0.96$ & 6.6 & $2 \pm 1.6$ & $0.23 \pm 0.2$ & 25 & 94.5 & 8.9 \\
\hline 27 & $30 \pm 20$ & $2.4 \pm 1.3$ & 34.4 & $56 \pm 19$ & $9.1 \pm 3.1$ & 27 & 23.2 & 2.2 \\
\hline - & - & - & 8.2 & $40 \pm 35$ & $3.1 \pm 1.6$ & 3 & 10 & 0.8 \\
\hline 10.6 & $0.9 \pm 0.3$ & $0.09 \pm 0.04$ & 19.7 & $1.5 \pm 0.5$ & $0.22 \pm 0.09$ & 16 & 4.4 & 0.4 \\
\hline 23.4 & $37 \pm 17$ & $2.7 \pm 1.3$ & 34.4 & $114 \pm 69$ & $7.9 \pm 2.5$ & 30 & 114 & 10.5 \\
\hline
\end{tabular}

Roots are not of any great importance as food. They are most often encountered in winter, and least often in spring. Of the roots identified the following two species occurred most frequently - Taraxacum officinale L. and Vaccinium myrtillus L.

The amount of fungi consumed by wild boar depends on whether these animals receive supplementary food. If so, then there are very few fungi found, e.g. in north-eastern Poland. When there is no supplementary feeding in winter, however, they form one of the basic foods of these animals. In the forest administration district of Nowogród (Forest districts Kuzie and Serafin) Elaphomices granulatus Fr. was consumed from autumn to summer. In January 1976 seven stomachs were obtained -4 of these were empty, while 3 contained $35 \%$ of sporocarps of Elaphomices granulatus Fr. Residues of this species formed $10 \%$ in excrement samples from the winter period.

Invertebrates were found in $16 \%$ of the stomachs, but their percentage and weight were very small. Bibionidea and Tipulidae larvae, which live in the soil, were most often found. Bibionidae are consumed chiefly in winter, when the wild boar root in the soil. Earthworms (Lumbricidae) are very often eaten in spring (results of observations of tame wild boar), and they were most often found in stomachs in summer, for instance one stomach contained $300 \mathrm{~g}$ of earthworms, which forms $50 \%$ of the total food mass. In 1975-1976 there was gradation in foci of Diprion pini L. in the Nowogród forest administration district. Soil samples showed that wild boar destroy up to $41 \%$ of Diprion pini L. (Genov, in print). The size of the cocoons is, however, so small that the 
wild boar would have to root over an enormous area to satisfy its hunger. The stomachs obtained during this period contained few of these pests, but on account of the small number of stomachs at our disposal it was difficult to reach any conclusion as to what degree the wild boar consumes this pest.

Vertebrates were found in $30 \%$ of the stomachs. In spring $4100 \mathrm{~g}$ of chicken offal originating from supplementary feeding was found in one stomach. Usually only one mouse was found per stomach; only in one case were two mice found. Fairly frequently it proved impossible to determine either the amount or species of the remains of rodents and other vertebrates contained in the wild boar stomachs. A frog and three nestlings were found in one stomach, and the skin of a roe deer in another (the skin probably came from a deer which had died naturally).

In general it may be said, that animal food does not play a basic part in the diet of wild boar.

As material was available from two different regions of Poland, comparison was made of the consumption of the various food components by wild boar in these regions and at different seasons of the year (cf. Figs 2 and 3). Analysis shows that in both regions potatoes form one of the basic components of the wild boar's diet, in addition to the fact that fotatoes are also used for supplementary feeding. Potatoes are consumed more intensively in the north-eastern region, where they were found in an average of $55.4 \%$ of the stomachs examined, than in the western region, where the average figure was $27.9 \%$ of stomachs (Fig. 2). The considerably greater proportion of potatoes in spring in the western region is due to the fact that samples were taken in April, when potatoes are planted in this region, and the wild boar root them up from the fields. In northern Poland potatoes are usually not planted until May, and therefore occur in stomachs obtained during the supplementary feeding period. Although it is not possible to compare consumption of potatoes by wild boar in spring in the two regions, the annual average of their consumption is greater in the north-eastern region (Fig. 3).

Maize was found in an average of $19.6 \%$ of stomachs from the northeastern region and in $44.2 \%$ of stomachs from the western region. It may be assumed that this is due to differences in its availability between the two regions. Very little maize is sown in the north of Poland and it is used in small quantities only during the supplementary feeding period. In the western region maize often occurs in cultivated fields, and therefore in the autumn (when maize ripens) it is far more often found in the wild boar stomachs. Maize may therefore be considered as one of the basic components of the wild boar's food, like sugar beet. In the north-eastern region wild boar are supplied with sugar beet in 

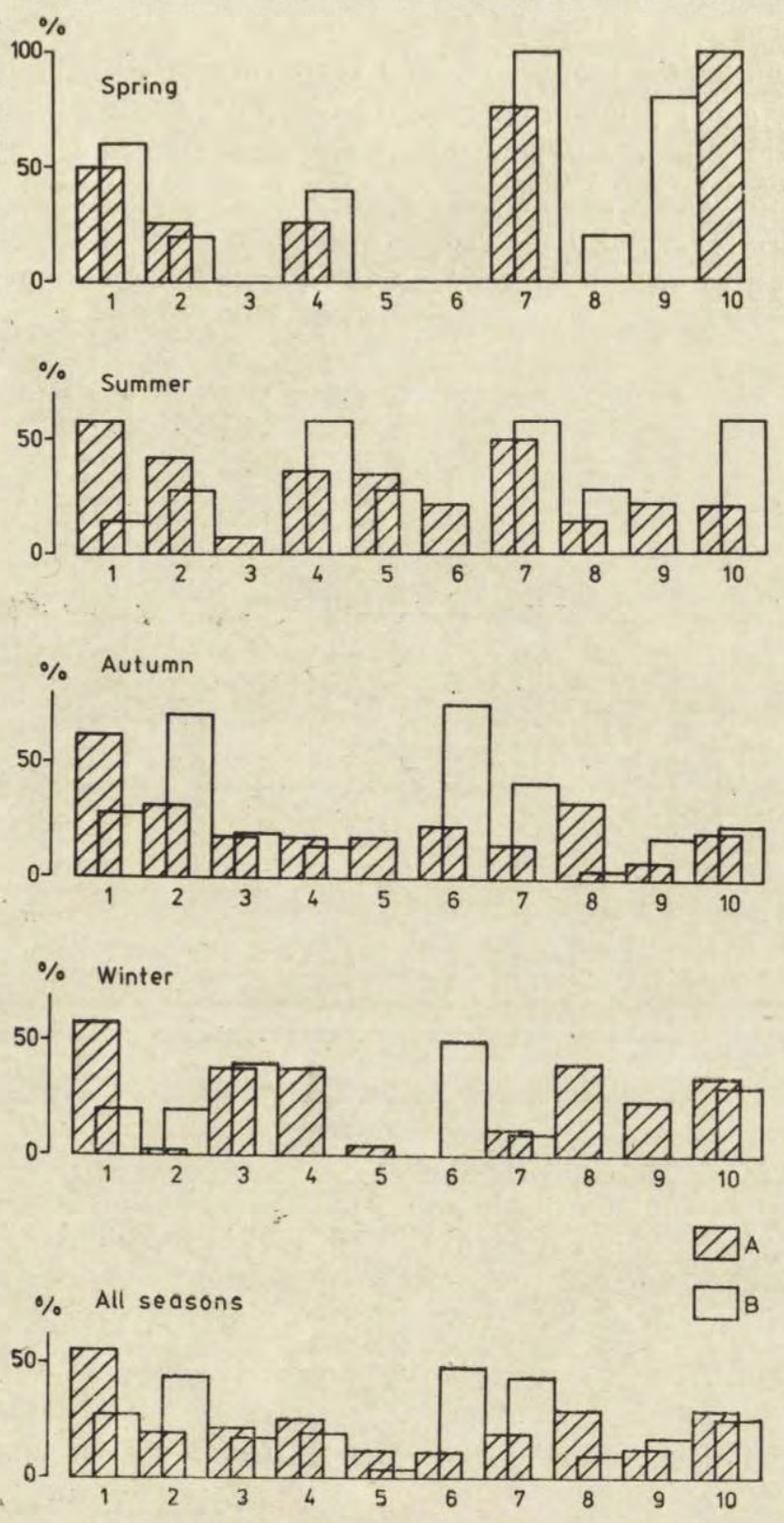

Fig. 2. Frequency of occurrence of different kinds of food in the wild boar's diet. Numbers indicate kind of food: 1 - potatoes, 2 - maize, 3 - sugar beet, 4 oats, 5 - rye, 6 - acorns, 7 - wild annual plants, 8 - roots, 9 - invertebrates, 10 - vertebrates. A - north-eastern Poland, B - western Poland. 
autumn and winter. Sugar beet is often cultivated in the western region and part of the crop remains in the fields.

Oats form one of the basic components of diet for which the wild boar searches. This crop occupies a relatively small area in both regions and has a short growing period. It is used for supplementary feeding wild boar in winter. Rye and wheat are consumed to a very small degree in both regions.

There are no leguminous crops in the north-eastern region, but in the western region wild boar feed on the green mass and pods in summer

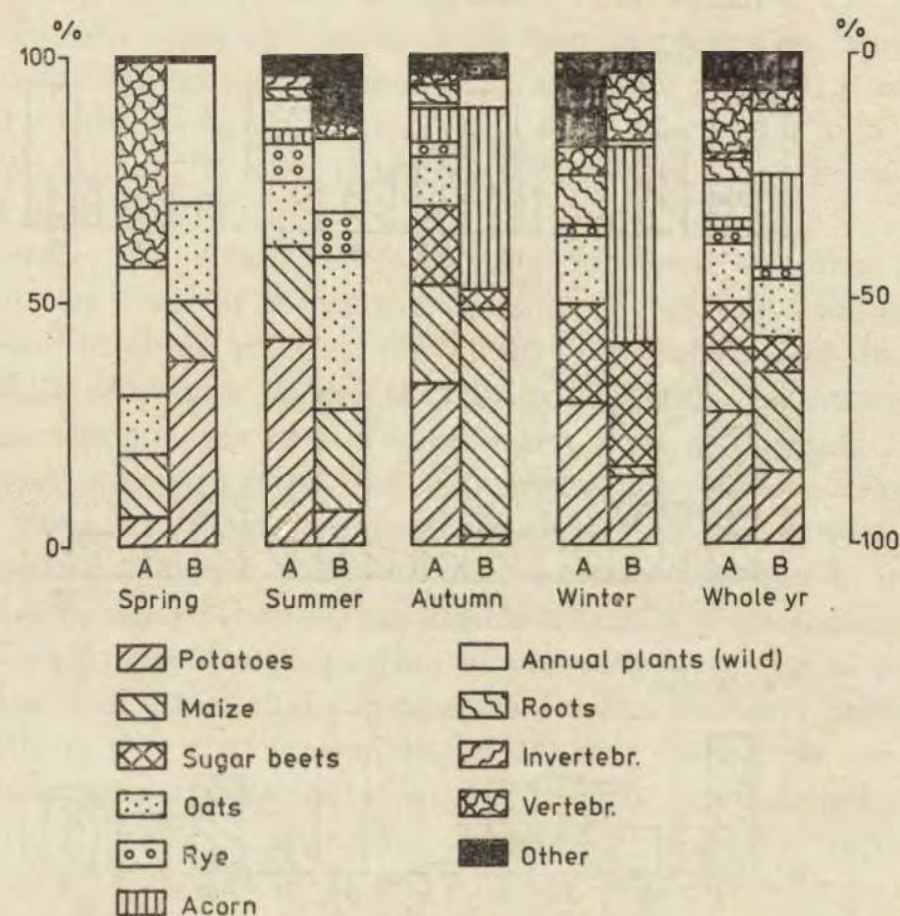

Fig. 3. Role of different kinds of food in the wild boar's diet. A - in north-eastern Poland, B - in western Poland.

and autumn. Acorns form a basic food in the western region and consequently during periods of good acorn crops little damage is done in cultivated fields. Annual plants are consumed almost uniformly in both regions. It was found that they constitute one of the basic food components in spring and summer, but participate in the wild boar's diet very little in autumn and winter.

Very few roots are found in the wild boar's food in the western region, and they are completely absent in winter. Relations are similar in the 
north-eastern region, although in this case they are found in autumn and winter. It is thus clear that roots are not of any great importance as food in either region.

Fungi were found in winter only in the north-eastern region, but were absent in the western region.

Animal food is not of importance in either region, but is regularly consumed as a supplementary food (Fig. 3).

\section{DISCUSSION}

An increase in the number of species (or higher taxons) of woodland and meadow plants consumed by wild boar has been observed in Central Europe in a direction from west to east (Table 7). It would appear that this is connected with the character of forests. In areas situated in the western part of Central Europe there are more coniferous forests poorer

Table 7

Number of taxons and percentage in weight of stomach contents of plants and animals in the wild boar's food in Central Europe.

\begin{tabular}{|c|c|c|c|c|c|c|c|c|}
\hline \multirow{2}{*}{ Item } & \multirow{3}{*}{$\begin{array}{c}\text { GDR } \\
665\end{array}$} & \multicolumn{2}{|c|}{ Poland } & \multicolumn{2}{|l|}{$\begin{array}{l}\text { Czecho- } \\
\text { slovakia }\end{array}$} & \multicolumn{2}{|c|}{ USSR $^{1}$} & \multirow[b]{2}{*}{306} \\
\hline & & 280 & 192 & 24 & - & 26 & 60 & \\
\hline & & & & & & & & \\
\hline Wild & 32 & - & 59 & - & - & 93 & 104 & 80 \\
\hline Cultivated & 12 & - & 14 & - & - & 6 & 7 & 10 \\
\hline Total & 44 & 一 & 73 & 53 & 61 & 99 & 111 & 98 \\
\hline Animals & & & & & & & & \\
\hline Invertebr. & 50 & 一 & 45 & 24 & - & 7 & 7 & 15 \\
\hline Vertebr. & 30 & - & 12 & - & - & 3 & - & 7 \\
\hline Total & 80 & - & 57 & 24 & 8 & 10 & 7 & 22 \\
\hline $\begin{array}{l}\text { Percentage of: } \\
\text { Plants }\end{array}$ & & & & & & & & \\
\hline $\begin{array}{l}\text { Plants } \\
\text { Animals }\end{array}$ & $\begin{array}{c}90 \\
4.5\end{array}$ & $\begin{array}{r}92.6 \\
6.2\end{array}$ & $\begin{array}{r}91 \\
9\end{array}$ & $\begin{array}{l}85.9 \\
13.2\end{array}$ & - & $\begin{array}{l}80.7 \\
19.3\end{array}$ & $\begin{array}{l}87.6 \\
12.4\end{array}$ & $\begin{array}{r}95.8 \\
4.2\end{array}$ \\
\hline Ref. no. & 2 & 8 & $\begin{array}{l}\text { this } \\
\text { paper }\end{array}$ & 11 & 21 & 20 & 15 & 14 \\
\hline
\end{tabular}

${ }_{1}$ Eastern part of the Białowieża Primeval Forest

in species than deciduous forests, which occur more frequently in the eastern part of Central Europe.

Cultivated plants form the basic food of wild boar all over Europe. They consume chiefly potatoes, maize, oats and rye, the composition of their diet depending on the frequency of occurrence of the different crops in the given region.

The data obtained in this study indicate that cultivated plants form $71 \%$ of the total food mass. This is a higher proportion than that given 
by, e.g., Janda (1958) for Czechoslovakia, where cultivated plants formed $14.4 \%$ of the total food mass consumed by wild boar. This low proportion of cultivated plants may be considered to be due to the specific character of the study area, which was a mountainous region with little cultivated land, but large stretches of deciduous forest. It may be assumed that in such an area the supply of natural food is sufficient and the wild boar are not obliged to emerge from wooded land into fields. Briedermann (1968) states that in years of poor acorn and beechnut crops cultivated plants constituted $90 \%$ of the total food mass consumed by wild boar, and in years of good acorn and beechnut crops, only $50-60 \%$, the average being $72.5 \%$.

Woodland and meadow plants formed an average of $20 \%$ of the total food mass. They are preferred to a greater degree in spring than in the other seasons, and form the chief food of wild boar. Their importance is conditioned by the growing season and the attractiveness to the wild boar of, for instance, acorns or beechnuts. The proportion of woodland and meadow plants consumed by wild boar increases in areas with a larger number of deciduous forests. Janda (1958) stated that these plants formed $71.4 \%$ of the total food mass, consisting chiefly of grass and nettles.

Only small amounts of animal food were found. In the study material 57 species or higher taxons were identified. Although the proportion of animals in the wild boar's food is not significant, a certain regularity may be observed - the number of species decreases from west to east (Table 7). In the case of mass occurence of rodents (Oloff, 1951) or pest insects (Haber, 1950, 1952, 1966), or where there is a large amount of carrion (Timofeeva 1976), wild boar consume this kind of food and it may then acquire basic importance.

The results obtained indicate that animal food formed $9 \%$ of the total mass, and is thus not of quantitative significance in wild boar's diet (Table 7), although it is an essential component.

Consumption by wild boar of the upper and underground parts of plants was compared. The upper parts are consumed more often in spring and summer, and they form a basic food during the growing season. The underground parts of plants are more often consumed in winter at the end of the growing season, when the wild boar search for food in the soil and are provided with potatoes and sugar beet as supplementary food (Table 5). The results obtained differ slightly from those of Lebedeva (1956), according to which the underground parts of plants form on an annual average $50 \%$, and upper parts of plants $31.6 \%$, of the wild boar's food. In spring, however, the upper parts of plants predominate $\left(52.7^{\%} \%\right)$, forming a basic food during this period. 
Direct observations of tame wild boar's confirmed their omnivorous habits. They search all possible habitats and consume every type of food they encounter (Genov, in print). Materials from different studies in various parts of Europe and Asia combined together give a picture of a very plastic species, rapidly adapting itself to varying food and climatic conditions. This becomes also clear when comparing the composition of wild boar's diet in the two study regions of Poland (Fig. 3).

The wild boar may be treated as an omnivorous species with a wide food spectrum and great ecological valence. As plant food always distinctly predominates in its diet, it must be considered as a I order consumer in the food chain of the ecosystem. Animal food forms only $9 \%$ of the food mass consumed. The wild boar may thus simultaneously be treatled, and only to a small degree, as an unspecialized II order consumer. The fact merits attention here that animal food is consumed primarily in natural habitats (forest, meadow). Thus the function of the wild boar as II order consumer in natural habitats is greater than it would appear to be from these general considerations. Depending on the type of habitat, the wild boar may carry out a different trophic function in natural and artificial biocenoses. Thus in areas in north-eastern Poland it is closely connected with forest ecosystems. In western Poland the wild boar inhabits small shelterbelts from spring to autumn, and even winter, and may be considered as belonging to agrocenoses. The closeness of the wild boar's connection with agrocenoses therefore depends not only on the abundance and variety of the food supply in forest habitats, but also (and to a great extent) on the structure of the landscape.

\section{REFERENCES}

1. Briedermann L., 1968: Die biologische und forstliche Bedeutungen des Wildschweines im Wirtschaftswald. Arch. Forstwes., 17: 943-967.

2. Briedermann L., 1976: Ergebnisse einer Inhaltsanalyse von 665 Wildschweinmagen. Zool. Garten N. F. Jena, 46: 157-185.

3. Dormidontov P., 1967: Kaban v Podmoskove. Ohota i ohotn. hozjastwo, 5 (1967): $11-13$.

4. Dzięciołowski R., 1967: Metody badania pokarmu dużych ssaków roślinożernych. Ekol. pol., Ser. B, 23: 38-46.

5. Genov P., in print: Znaczenie biocenoz naturalnych i agrocenoz jako bazy pokarmowej dzika (Sus scrofa L.). Ekol. pol.

6. Haber A., 1950: W obronie dzików. Łowiec pol., 6 (979): 4-8.

7. Haber A., 1952: Próba wyjaśnienia wpływu kręgowców na populacje osnui gwiaździstej. Prace IBL, 85: 1-15.

8. Haber A., 1966: Pó̇ywienie dzika. Łowiec pol., 14 (1281): 2-3.

9. Haber A., 1968: Biotopy występowania dzika (Sus scrofa L.) na terenach Polski 
i jego pożywienie pochodzenia roślinnego. Zesz. nauk. Szk. Główn. Goṣp. wiejsk., Leśn., 10: 7-31.

i0. Haber A., 1969: Dzik. Monografia przyrodniczo-łowiecka. Państw. Wyd. Roln. i Leśne: 1-216. Warszawa.

11. Janda M., 1958: Die Nahrung des Schwarzwild (Sus scrofa L.) im Mittelgebirgsgebiet von Stavnica. Säugetierkdl. Mitt., 6: 67-74.

12. Kozlo P. G., 1969: Pitanie kabana i sezonnaja smena ego korma. Belovežsskaja pušča, Issledovanija, 3: $132-144$.

13. Kozlo P. G.,1972: O sostave osenne-zimnih kormov dikogo kabana (Sus scrofa L.), Berezinski zap., 2: 133-140.

14. Kozlo P. G., 1975: Dikii kaban. Urožaj: 1-223. Minsk.

15. Lebedeva A., 1956: Ekologičeskije osobennosti kabana Belovežskoj Pušči. Uč. Zap. mosk. gorodsk. ped. Inst., $61: 105-271$.

16. Lozan M. N., Lozan A. M. \& Panicerska O. J., 1978: Ekologo-etologiceskie aspekty pitania kabana (Sus scrofa L.) Moldavii. Sb. „Fauna, ekologia i fizjologija Životnyh": $38-46$.

17. Oloff H. B., 1951: Zur Biologie und Okologie des Wildschweines. Paul Schöps Verl.: 1-95. Frankfurt a. M.

18. Pasławski T., 1976: Opracowanie zasad zagospodarowania leśnych obwodów lowieckich mającego na celu zmniejszenie szkód od zwierzyny z uwzględnieniem letniego dokarmiania. Dokumentacja IBL 4, 109: 1-27.

19. Rzebik-Kowalska B. R., 1972: Badania nad pokarmem ssaków drapieżnych w Polsce. Acta zool. cracov., 17: 416-504.

20. Sablina T. B., 1955: Kopytnye Belovežskoj pušči. Tr. Inst. Morfol. životn., 15: 20-114. Moskva.

21. Severcov A. A. \& Sablina T. B., 1953: Oleń, kosula i kaban v zapovednike Belovežskaja pušča. Tr. Inst. Morfol, Životn., 9: 140-230.

22. Sumiński P., 1963: Dzik. Szkic monograficzny. Łowiec pol., 1 (1196): 3-6, 2 (1197): 34, 3 (1198): $4-6$.

23. Timofeeva E. K., 1976: Stacial'noe raspredelenie i pitanie kabana na severnom predele ego rozprostranenija. Tr. Petergof. biol. Inst., 24: 107-121.

24. Varnakov A. R. \& Moseva T. S., 1975: Rol' kabana v selskom hozjaistve Moskovskoj oblasti. Sb. „Kopytnye fauny SSSR”: 161-162. Moskva.

Accepted, December 10, 1980.

Peter GENOV

\section{POKARM DZIKA W POLSCE POENOCNO-WSCHODNIEJ I ZACHODNIEJ}

\section{Streszczenie}

Przeprowadzono analizę składu pokarmu dzików, Sus scrofa Linnaeus, 1758 na podstawie 192 żołądków zebranych w dwóch rejonach Polski: północno-wschodnim i zachodnim (Ryc. 1, Tabela 1). W pokarmie dzików wyróżniono 59 gatunków lub wyższych taksonów roślin dzikich, 14 gatunków roślin uprawnych i 57 gatunków lub wyższych taksonów systematycznych zwierząt (w tym 45 bezkręgowców i 12 kręgowców) oraz padlinę (Tabela 2).

Dzik jest w zasadzie zwierzęciem o aktywności nocnej. Znajduje to odbicie w przeprowadzonych analizach żołądków. Wszystkie żołądki dzików zdobyte przed 
południem (do godz. 12.00) zawieraly większą średnią masę pokarmu niż zdobyte po godz. 12.00 (Tabela 3).

Najczęściej spotykanym typem pokarmu byly rośliny uprawne. Występowały one w $89 \%$ żołądków i stanowiły średnio $71 \%$ treści żołądków (Tabela 4). Drugim typem pokarmu dzików są rośliny występujące dziko. Spotykano je w $64 \%$ żołądków a stanowily one średnio $20 \%$ zawartości żołądków. Pokarm roślinny jest podstawowym pokarmem dzików przez cały rok. Występuje on w $99 \%$ żołądków i stanowi $91 \%$ ich zawartości (Tabela 4).

Pokarm zwierzęcy wykorzystywany jest w ciągu calego roku. Znajdowano go w $47 \%$ żołądków zawierających pokarm. Stanowił on jednak średnio tylko $9 \%$ ciężaru zawartości żołądków.

Nadziemne części roślin występują przeciętnie w ciągu roku w 73,5\% żołądków, a ich średni ciężar wynosi $673,5 \mathrm{~g}$, co stanowi $53 \%$ treści żołądków. Podziemne części roślin występują w $65.8 \%$ żołądków. Wykorzystywane są one najczęściej jesienią i zimą, podczas gdy nadziemne części roślin - wiosną i latem (Tabela 5).

W obu badanych regionach Polski dziki wykorzystują przede wszystkim ziemniaki i owies, a w zachodnich częściach kraju także kukurydzę i buraki cukrowe (Ryc. 2 i 3). Z roślin dzikich - żołędzie stanowią w Polsce zachodniej podstawowy pokarm. Istotnym składnikiem pokarmu dzika w obu rejonach są jednoroczne rośliny zbiorowisk leśnych i łąkowych.

Pokarm zwierzęcy jest wykorzystywany w obu rejonach w ciągu całego roku $\mathrm{w}$ małych ilościach, $\mathrm{z}$ wyjątkiem padliny, która pochodzi $\mathrm{z}$ dokarmiania dzików w okresie zimowym.

Duża walencja ekologiczna dzika umożliwia temu gatunkowi latwe przystosowanie się do zmieniającej się struktury krajobrazu. W związku z tym siła związku dzika $z$ agrocenozami zależy nie tylko od bogactwa i zasobności siedlisk leśnych ale również i to w znacznym stopniu, od struktury krajobrazu. 